\title{
A New Alloantigen, Ly-8, Recognized by C3H Anti-AKR Serum
}

\author{
Jeffrey A. Frelinger and Donal B. Murphy \\ Department of Microbiology, University of Southern California Medical School, \\ Los Angeles, California 90033 ; \\ Division of Immunology, Department of Medicine, \\ Stanford Medical School, Stanford, California 94305; \\ Department of Human Genetics, University of Michigan School, Ann Arbor, Michigan 48109
}

Received March 9, 1976

\begin{abstract}
A new membrane alloantigen, designated $\mathrm{Ly}-8.2$, is defined by a $\mathrm{C} 3 \mathrm{H}$ anti-AKR serum. The locus, $L y-8$, which controls this determinant is not linked to Thy-1,Ly-4,Ly-6,H-2, albino (c), or brown $(b)$. Ly- 8.2 has a unique strain distribution, and appears to be present on both $T$ and B lymphocytes.
\end{abstract}

\section{Introduction}

Anti-Thy-1 sera have been used widely as tools for detection of $\mathrm{T}$ cells in functional studies (Raff 1971). The possibility of other antibodies' contaminating the classical anti-Thy-1 sera has already been raised. Greaves and Raff (1971) noted that AKR anti-CBA sera contained antibodies which were cytotoxic to CBA B cells and were absorbed with CBA thymus, but not CBA brain cells. No further serological or genetic characterization of this specificity has been reported. Further, the presence of anti-immunoglobulin allotype has been reported (Baird et al. 1971), and anti-Ly-1 or anti-Ly-3 have been predicted in such sera on the basis of strain distribution. In this report, a new alloantigen system defined by the reactivity of a $\mathrm{C} 3 \mathrm{H}$ anti-AKR serum with $\mathrm{C} 57 \mathrm{BL} / 10$ (abbreviated to $\mathrm{B} 10$ ) tissue is described. The locus controlling this activity is not linked to Thy-1, $L y-4$, $L y-6, H-2$, albino (c), or brown (b). Determinants controlled by this system can be detected on both $\mathrm{T}$ and $\mathrm{B}$ lymphocytes. The locus is tentatively designated as $L y-8$, the allele $L y-8^{b}$, and the antigen it determines, Ly-8.2.

\section{Materials and Methods}

Mice were either raised in the animal facility at the University of Michigan's Department of Human Genetics, or purchased from the Jackson Laboratory, Bar Harbor, Maine, or from Cumberland Farms, Clinton, Tennessee. (BALB/c $\times \mathrm{C} 57 \mathrm{BL} / 6) \mathrm{F}_{1} \times \mathrm{BALB} / \mathrm{c}$ mice were generously provided by Ann Feeney, Memorial-Sloan Kettering Cancer Institute, New York.

Four anti-Thy-1 sera were used in this study. AKR/J anti-C3H/HeJ and A.AKR anti-A.AL (both anti-Thy-1.2), and $\mathrm{C} 3 \mathrm{H}$ anti-AKR/J (anti-Thy-1.1) were produced according to the method of Reif and Allen (1966) by weekly injections of $10^{7}$ thymocytes per recipient. AKR/Cum anti-AKR/J (anti-Thy-1.1) serum was provided by E.P. Blankenhorn, California Institute of Technology, Pasadena. This serum is produced in AKR sublines which differ at Thy-1 (Acton et al. 1973). All antisera tested 
were from large batches of pooled sera. A.AKR $\left(T h y-1^{a}\right)$ and A.AL $\left(T h y-1^{b}\right)$ are a congenic strain pair which differ only at $T h y-1$.

Anti-Ly-6,2 serum [(A $\times$ BALB/c) anti-CXBD] was provided by Dr. Marianna Cherry, Jackson Laboratory, Bar Harbor, Maine. Anti-Ly-4.2 [(SWR $\times$ BALB/c) anti-B10.D2] was prepared as described previously by Snell and coworkers (1973). Anti-H-2.13 serum was produced in (B10.BR $X$ A.BY) $F_{1}$ by immunizing with B10.AKM tissue.

A two-stage dye exclusion test using rabbit complement was performed according to the method of Amos and coworkers (1969), as modified by Frelinger and coworkers (1974). Hemagglutination assays and in vitro absorption analyses were conducted as described previously (Frelinger et al. 1974, Stimpfling 1961). Direct plaqueforming cells were assayed by the method of Jerne and Nordin (1963). Splenic or lymph node T cells were purified on nylon wool columns (Julius et al. 1973).

\section{Results and Discussion}

Treatment of AKR lymph node or thymus cells with a $\mathrm{C} 3 \mathrm{H}$ anti-AKR serum in the presence of rabbit complement results in 60 to 70 percent or 100 percent lysis, respectively. In contrast, 60 to 70 percent of $\mathrm{B} 10(\mathrm{C} 57 \mathrm{BL} / 10 \mathrm{SgSnSf})$ lymph node cells are killed by this antiserum, while less than 15 percent of B10 thymus target cells are lysed (Fig. 1). In order to determine whether two antibody populations are involved, an in vitro absorption analysis was conducted. Absorption with B10 or AKR thymus cleared all activity for B10 lymph node targets (Fig. 2). B10 thymus completely removed activity for B10 lymph node targets (top panel), while leaving reactivity for both $\mathrm{AKR}$ lymph node and thymus cells (bottom two panels). In no case did $\mathrm{C} 3 \mathrm{H}$ cells remove any activity, suggesting that no autoantibody is being detected in this reaction. Absorbing with AKR/J lymph node cells gave results equivalent to those obtained with AKR thymus cells. These data suggest that this serum recognized two distinct determinants - one expressed only on AKR cells (Thy-1.1), the other shared by B10 and AKR (Ly-8.2). B10 kidney, liver, and brain did not absorb activity for B10 lymph nodes.

Since $\mathrm{C} 3 \mathrm{H}$ and $\mathrm{B} 10$ share the same Thy-1 ${ }^{b}$ allele, reactivity with $\mathrm{B} 10$ should not involve antibody directed against Thy-1.1 determinants. This conclusion is supported by the marginal direct reaction observed with B10 thymus target cells.

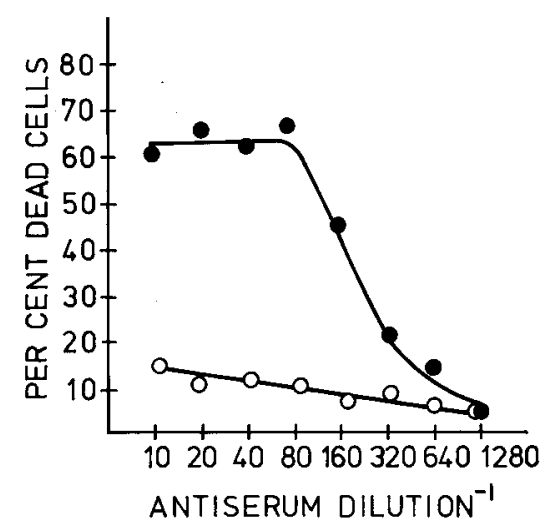

Fig. 1. Direct cytotoxic test of C3H anti-AKR: B10 lymph node lymphocytes $\bullet-\bullet$; B10 thymus cells $0-0$ 


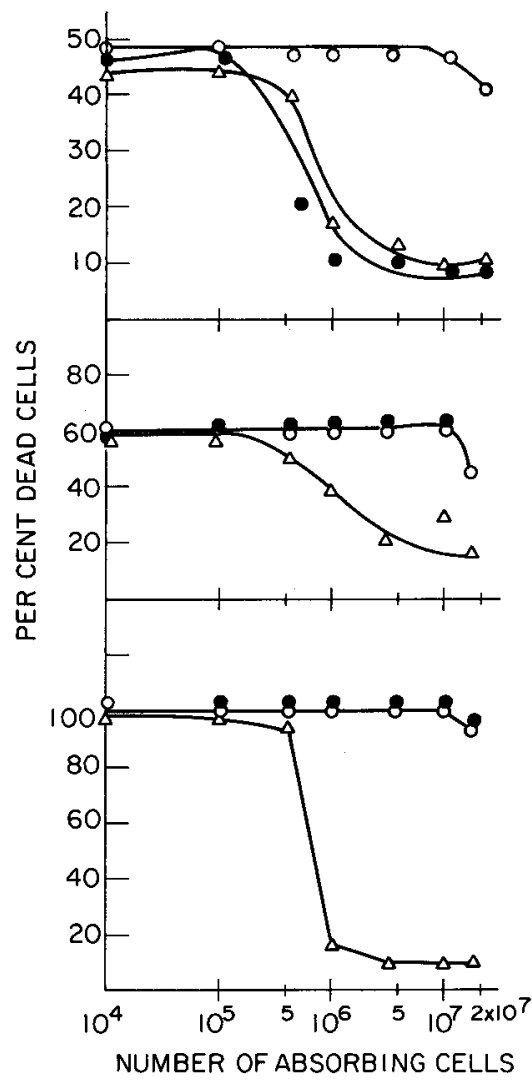

Fig. 2. Absorption analysis of $\mathrm{C} 3 \mathrm{H}$ anti-AKR serum. Top panel shows the absorption of $\mathrm{C} 3 \mathrm{H}$ anti-AKR diluted $1 / 100$ by $\mathrm{B} 10 \bullet-$, AKR $\triangle-\triangle$, or $\mathrm{C} 3 \mathrm{H} \bigcirc-\mathrm{O}$ thymus cells for B10 lymph node targets. Center panel shows absorption of $\mathrm{C} 3 \mathrm{H}$ anti-AKR by B10 - , AKR $\triangle-\triangle$, or $\mathrm{C} 3 \mathrm{H} \bigcirc-\mathrm{O}$ thymus cells for AKR lymph node target cells. Bottom panel shows the same absorbed sera tested with AKR thymus target cells

Thy-1 antigens normally are easily detected on this cell population. In addition, strain A.AKR thymus cells, which express Thy-1.1 determinants, fail to absorb reactivity for $\mathrm{C} 57 \mathrm{BL} / 10$ lymph node cells. In order to verify that $L y-8$ and $T h y-1$ are distinct genetic loci, a linkage test was performed. (AKR.M $\times$ C $3 \mathrm{H}$ ) $\mathrm{F}_{1}$ mice were backcrossed to $\mathrm{C} 3 \mathrm{H}$ mice, and the progeny were typed for Thy-1, $L y-8$, and $H$-2 (Table 1). AKR.M mice were used to provide an $H-2$ marker. Of thirty-six backcross mice, 26 reacted with the $\mathrm{C} 3 \mathrm{H}$ anti-AKR/J serum (anti-Thy-1.1, anti-Ly-8.2). This result clearly demonstrates the segregation of two unlinked genes. Thy- $1^{b}$ homozygous animals were determined by a negative reaction with an AKR/Cum anti-AKR/J (anti-Thy-1.1) serum. Of sixteen Thy-1 $1^{b}$ homozygotes, six were typed Ly-8.2. These data show that $L y-8$ and Thy-1 are independent loci. Typing these same mice for $\mathrm{H}-2.13$ (marker for $H-2 D^{q}$ ) indicates that $L y-8$ is not linked to $H-2$ (Table 1 ). 
Table 1. Segregation of $L y-8$ and Thy-1,H-2

\begin{tabular}{|c|c|c|c|c|c|}
\hline \multirow[t]{2}{*}{ Loci Tested } & \multicolumn{4}{|c|}{ Number of Mice In Each Class } & \multirow[t]{2}{*}{ Cross } \\
\hline & ++ & +- & -+ & -- & \\
\hline Thy-1 vs. $L y-8$ & (20) & & 6 & 10 & $(\mathrm{C} 3 \mathrm{H} \times \mathrm{AKR} \cdot \mathrm{M}) \mathrm{F}_{1} \times \mathrm{C} 3 \mathrm{H}$ \\
\hline$H-2$ vs. $L y-8$ & 3 & 6 & 3 & 4 & $(\mathrm{C} 3 \mathrm{H} \times \mathrm{AKR} . \mathrm{M}) \mathrm{F}_{1} \times \mathrm{C} 3 \mathrm{H}$ \\
\hline
\end{tabular}

Table 2. Strain Distribution of $L y-8$

\begin{tabular}{llll}
\hline Strain & Thy-1 & C3H $\alpha$ AKR Ly-8.2 & AKR $\alpha$ C 3 H Ly-8.1 \\
\hline A/WySnSf & $b$ & - & $(+)^{\mathrm{a}}$ \\
BALB/cJ & $b$ & - & $?$ \\
CBA/J & $b$ & - & $?$ \\
C57BL/10SgSnSf & $b$ & + & $?$ \\
C57BR/cdJ & $b$ & + & $?$ \\
C57L/J & $b$ & + & $?$ \\
C3H/HeSf & $b$ & - & + \\
DBA/1Fs & $b$ & - & $?$ \\
DBA/2Fs & $b$ & + & $?$ \\
HTG/Sf & $b$ & + & $?$ \\
SJL/J & $b$ & + & $?$ \\
SM/J & $b$ & + & $?$ \\
SWR/J & $b$ & + & + \\
A.AKR/Sf & $a$ & +- & - \\
AKR/J & $a$ & + & \pm \\
BDP/J & $a$ & $?$ & - \\
BUB/J & $a$ & $?$ & + \\
PL/J & $a$ & $?$ & + \\
RF/J & $a$ & $?$ & \\
\hline
\end{tabular}

${ }^{a}$ Deduced from reactivity of A.AKR.

Since the $\mathrm{C} 3 \mathrm{H}$ anti-AKR serum used in this study contains anti-Thy-1.1 antibody, one can test anti-Ly-8 activity directly only against $T h y-1^{b}$ strains. Similarly, one can test the reciprocal antiserum, AKR anti-C3H, only against Thy-1 ${ }^{a}$ strains. These results are presented in Table 2 . This strain distribution is unlike any other previously defined alloantigen system. Although we show in Table 2 the strain distribution of both antisera, we have no evidence to prove that the reciprocal sera recognize allelic products. We stress that, aside from the strain distribution shown here, all subsequent work was performed using the $\mathrm{C} 3 \mathrm{H}$ anti-AKR serum. The specificity defined by this antiserum is designated Ly-8.2. The antigen recognized by the reciprocal serum may or may not be Ly-8.1.

The strain distribution of Ly-8.2 is similar but not identical to the distribution of Ly-4.2 (Snell et al. 1973) and Ly-6.2 (Cherry, personal communication). Two crosses were examined to determine possible linkage to either system. In the first cross, the progeny of a $(\mathrm{C} 3 \mathrm{H} \times \mathrm{B} 10) \mathrm{F}_{1} \times \mathrm{C} 3 \mathrm{H}$ backcross were typed for $\mathrm{Ly}-8.2$ and Ly-4.2. These loci clearly segregate independently (Table 3 ). In the second 
Table 3. Segregation of Ly-8 and Ly-4, Ly-6, albinism (c) and brown (b)

\begin{tabular}{llllll}
\hline Loci Tested & \multicolumn{3}{c}{ Number of Mice in Each Class } & \multicolumn{1}{c}{ Cross } \\
\cline { 2 - 4 } & ++ & +- & -+ & - & \\
\hline$L y-4$ vs. $L y-8$ & 4 & 3 & 4 & 3 & $(\mathrm{~B} 10 \times \mathrm{C} 3 \mathrm{H}) \mathrm{F}_{1} \times \mathrm{C} 3 \mathrm{H}$ \\
$L y-6$ vs. $L y-8$ & 5 & 3 & 5 & 7 & $(\mathrm{C} 57 \mathrm{BL} / 6 \times \mathrm{BALB} / \mathrm{c}) \mathrm{F}_{1} \times \mathrm{BALB} / \mathrm{c}$ \\
C vs. $L y-8$ & 6 & 5 & 4 & 5 & $(\mathrm{C} 57 \mathrm{BL} / 6 \times \mathrm{BALB} / \mathrm{c}) \mathrm{F}_{1} \times \mathrm{BALB} / \mathrm{c}$ \\
$b$ vs. $L y-8$ & 2 & 2 & 2 & 2 & $(\mathrm{C} 57 \mathrm{BL} / 6 \times \mathrm{BALB} / \mathrm{c}) \mathrm{F}_{1} \times \mathrm{BALB} / \mathrm{c}$ \\
\hline
\end{tabular}

cross, $(\mathrm{BALB} / \mathrm{c} \times \mathrm{C} 57 \mathrm{BL} / 6) \mathrm{F}_{1} \times \mathrm{BALB} / \mathrm{c}$ backcross animals were typed for Ly-8.2 and Ly-6.2. Again, no linkage is apparent (Table 3). The same mice were classified for coat color. No linkage to the albino $(c)$ or brown (b) loci was evident. In all linkage tests, $\chi^{2}$ analysis showed no significant deviation from 50 percent recombination (unlinked genes). These data suggest that $L y-8$ is not on chromosome $2(L y-4)$, chromosome $4(b)$, chromosome $7(a)$, chromosome 9 (Thy-1), or chromosome $17(H-2)$.

The data thus far demonstrate that the $\mathrm{C} 3 \mathrm{H}$ anti-AKR serum contains two antibodies, anti-Thy-1.1 and anti-Ly-8.2. Potentially, this serum could also contain antibody against Ly-1.2, Ly-3.1, Ly-6.2, and Ly-7.2. One could argue that Ly-8.2 merely redefines one of these systems, but this possibility appears unlikely for several reasons. First, we have shown that Ly- 8.2 has a unique strain distribution, and that $L y-8$ and $L y-6$ segregate independently. Second, strains $\mathrm{C} 3 \mathrm{H}$ and B10 (the typing strain for Ly-8.2) share Ly-3.2 and Ly-7.1 determinants. Finally, Ly-1.2 and Ly-3.1 are readily detectable on thymocytes, whereas Ly-8.2 demonstrates only marginal activity with this cell population. The reaction cannot be caused by anti-Ly-5, since B10, C3H, and AKR all share the Ly-5.1 specificity (Komoro et al. 1975).

No reaction was observed with the $\mathrm{C} 3 \mathrm{H}$ anti-AKR serum in immunodiffusion tests against the donor serum. Further, the strain distribution of Ly-8.2 is unlike any previously defined allotype system. These observations suggest that the observed cytotoxic reactions are not the result of unknown antiallotype antibodies reacting directly with surface Ig of lymphocytes. Neither $\mathrm{C} 3 \mathrm{H}$ anti-AKR nor $\mathrm{AKR}$ anti-C3H has detectable hemagglutinating activity for donor red blood cells.

The 70 percent of cytotoxicity observed against lymph node lymphocytes suggests that reactivity cannot be limited to either the T or B population. Since B10 thymus cells completely absorb for B10 lymph node cells and the serum was produced against thymus preparations, at least some cells in the thymus-presumably $\mathrm{T}$ cells - express Ly-8. Direct cytotoxic tests with nylon wool-purified $\mathrm{T}$ cells (approximately 80 percent Thy-1-positive) from either spleen or lymph node show 60 to 70 percent sensitive cells (Fig. 3). This antiserum also kills B10 plaque-forming cells. Mice were primed intraperitoneally five days before sacrifice with $0.1 \mathrm{ml}$ of 10 percent burro red cells. Treatment of the in vivo-primed spleen with anti-Ly-8 and complement greatly reduced the number of direct plaqueforming cells (Table 4). Antiserum against Ly-4.2 - a known B-cell marker-also 


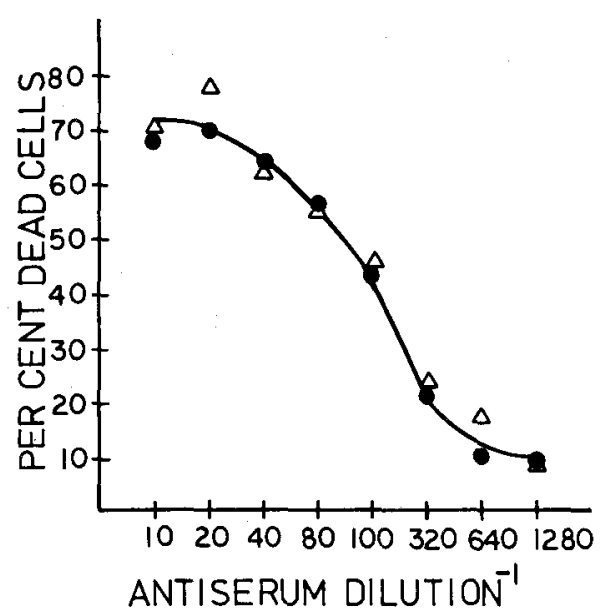

Fig. 3. Direct cytotoxic test of $\mathrm{C} 3 \mathrm{H}$ anti-AKR on purified T cells. Spleen $\bullet \bullet$, or lymph node $\triangle-\triangle$ nylon wool-purified $\mathrm{T}$ cells tested with decreasing concentrations of $\mathrm{C} 3 \mathrm{H}$ anti-AKR serum

Table 4. Effect of Anti-Ly-8 on B10 Direct Plaque-Forming Cells

\begin{tabular}{|c|c|}
\hline Treatment & $\mathrm{Pfc} / 10^{6}$ Viable Cells \\
\hline None & 888 \\
\hline Anti-Thy-1.2+c & 729 \\
\hline Anti-Ly- $4.2+c^{\prime}$ & 32 \\
\hline Anti-Ly-8.2+c & 56 \\
\hline
\end{tabular}

reduced the number of plaque-forming cells. Equal numbers of viable cells were tested in each case. These data clearly show that Ly-8 is expressed on both T cells and plaque-forming cells.

In order to test Ig-bearing cells directly, T-depleted B10 spleen cells were prepared by treatment with anti-Thy-1 and rabbit complement. The dead cells were removed by centrifugation on Lymphoprep, and the remaining cells were tested in direct cytotoxicity tests. This cell population is more than 80 percent Ig-positive by immunofluorescence. Anti-Ly-8.2 lyses approximately 60 percent of this cell population (Fig. 4). Anti-Thy-1.2 shows no detectable killing, demonstrating the absence of $\mathrm{T}$ cells in this preparation. Essentially all of these cells are sensitive to an appropriate anti-H-2 serum, showing that all the cells are susceptible to lysis. These results show that at least a portion of Ig-bearing cells express Ly-8 determinants.

We have presented evidence which defines a new alloantigen system, designated $L y-8$. Formal genetic linkage studies have shown that $L y-8$ is not linked to $L y-4$, $L y-6$, Thy-1, or $H-2$. A distinct pattern of reactivity with a standard panel of strains further suggests that this system is unlike any other which has been well characterized on lymphocytes. Greaves and Raff (1971) demonstrated anti-B cell activity in an AKR anti-CBA serum, but failed to characterize this activity further. It is possible that the antigen studied by these investigators is identical to that 


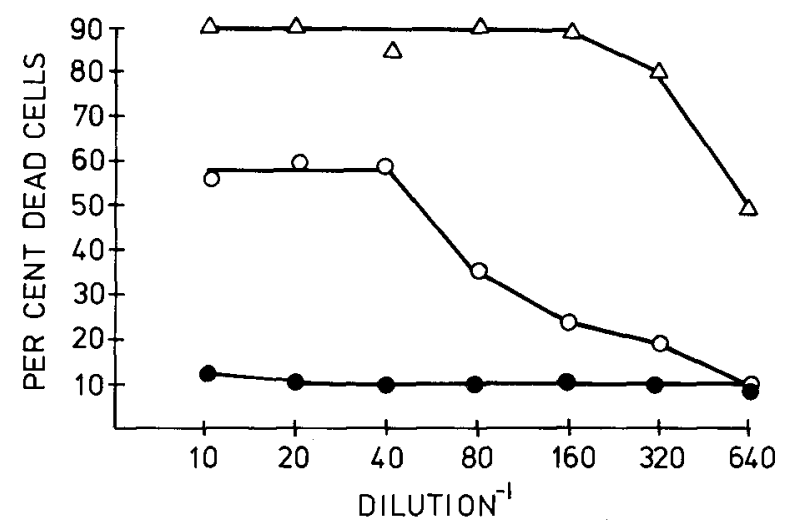

Fig. 4. Direct cytotoxic test of $\mathrm{C} 3 \mathrm{H}$ anti-AKR on Thy-1-depleted B10.D2 spleen cells: C3H anti-AKR O-O, anti-Thy-1.2 - $\bullet$ anti-H-2.4 $\Delta-\Delta$

detected in the AKR anti-C3H serum, but such an association is purely conjectural. Antigens detected by the $\mathrm{C} 3 \mathrm{H}$ anti-AKR serum are present on both $\mathrm{T}$ and $\mathrm{B}$ lymphocytes. Studies are currently underway to determine if this marker demarcates subsets in either $\mathrm{T}$ or $\mathrm{B}$ lymphocyte populations.

Acknowledgments. We thank Dr. Donald C. Shreffler for advice and support, and Mr. Reid Toda for technical assistance. This work is supported by USPHS Grant AI-11962, American Cancer Society California Division Grant 775, American Cancer Society Grant IM-90, and a Jane Coffin Childs grant. Portions of this work were performed when the authors were a Jane Coffin Childs Fellow (J.A.F.) and NIH predoctoral trainee (D.B.M.) at the University of Michigan.

\section{References}

Acton, R. T., Blankenhorn, E, P., Douglas, T. C., Owen, R. D., Hilgars, J., Hoffman, H. A., and Boyse, E. A.: Variations among sublines of inbred AKR mice. Nature (New Biol.) 245:8-11, 1973

Amos, D. B., Bashir, H., Boyle, W., MacQueen, M., and Tilikainen, A.: A simple microcytotoxicity test. Transplantation 7:220-222, 1969

Baird, S., Santa, J., and Wiessman, I.: Anti-theta antisera may contain anti-allotype contamination. Nature (New Biol.) 232:56, 1971

Frelinger, J.A., Niederhuber, J.E., David, C.S., and Shreffler, D.C.: Evidence for the expression of Ia antigens on thymus derived lymphocytes. J. Exp. Med. 140:1273-1284, 1974

Greaves, M.F. and Raff, M.C.: Specificity of anti-theta sera in cytotoxicity and functional tests on T lymphocytes. Nature New Biol. 233:239-242, 1971

Jerne, N.K. and Nordin, A. A.: Plaque formation in agar by single antibody producing cells. Science $140: 405,1963$

Julius, M., Simpson, E., and Herzenberg, L.A.: A rapid method for the isolation of thymus derived murine lymphocytes. Eur. J. Immunol. 3:645-649, 1973

Komoro, K., Itakura, K., Boyse, E.A., and John, M.: Ly-5: A new T lymphocyte antigen system. Immunogenetics 1:452-456, 1975

Raff, M.C.: Surface antigenic markers for distinguishing T and B lymphocytes in mice. Transplant. Rev. 6:52-80, 1971

Reif, A.E. and Allen, J. M.: Mouse thymic isoantigens. Nature (Lond.) 209:521-523, 1966

Snell, G.O., Cherry, M., McKenzie, I.F.C., and Bailey, D. W.: Ly-4, a new locus determining a cellsurface alloantigen in mice. Proc. Nat. Acad. Sci. USA 70:1108-1111, 1973

Stimpfling, J.: The use of PVP as a developing agent in mouse hemagglutination tests. Transplant. Bull. 27:109-111, 1961 